\title{
Laba Per Saham, Rasio Hutang, Pengembalian Atas Aset dan Suku Bunga Terhadap Nilai Perusahaan Wholesale
}

\author{
Mariska Sisilia, S.E., M.Si \\ Universitas Prima Indonesia, Medan \\ sisilia.mariska@yahoo.com

\section{Elise} \\ Universitas Prima Indonesia, Medan \\ liseoeeii@gmail.com \\ Rina Yustito.S \\ Universitas Prima Indonesia, Medan \\ rinayustitos@gmail.com

\section{Cherria Halim} \\ Universitas Prima Indonesia, Medan \\ cherriahalim@yahoo.com
}

\begin{abstract}
Abstrak Penelitian ini bertujuan untuk mengetahui pengaruh laba per share, rasio hutang, pengembalian atas asset dan suku bunga terhadap nilai perusahaan pada perusahaan whosale yang tercatat di BEI tahun 2014-2018. Penelitian ini dilakukan dengan metode penelitian asosiatif dan pendekatan kuantitatif. 17 perusahaan yang menjadi sampel diambil dengam metode purposive sampling. Model analisis menggunakan persamaan regresi linear ganda. Hasil dari penelitian adalah Laba per saham tidak berpengaruh terhadap nilai perusahaan pada perusahaan Whosale yang Tercatat di BEI. Rasio hutang tidak berpengaruh terhadap nilai perusahaan pada perusahaan Whosale yang Tercatat di BEI. Pengembalian atas aset berpengaruh terhadap nilai perusahaan pada perusahaan Whosale yang Tercatat di BEI. Suku bunga tidak berpengaruh terhadap nilai perusahaan pada perusahaan Whosale yang Tercatat di BEI. Laba per saham, rasio hutang, pengembalian atas aset dan suku bunga berpengaruh terhadap nilai perusahaan pada perusahaan Whosale yang Tercatat di BEI.
\end{abstract}

Kata Kunci Laba Per Saham, Rasio Hutang, Pengembalian Atas Aset, Suku Bunga dan Nilai Perusahaan

\section{PENDAHULUAN}

Sekarang inilah pasar modal Indonesia memiliki perusahaan yang banyak. Tujuan jangka pendek memperoleh laba dengan menggunakan sumber daya dimilikinya sedangkan jangka panjang perusahaan terdapat pemaksimalan nilai perusahaan. Nilai perusahaan ini menunjukkan kemakmuran pemegang saham. Nilai perusahaannya terlihat dari laba per saham, rasio hutang, pengembalian atas aktivanya maupun suku bunga yang tinggi maupun rendah.

Laba per saham menunjukkan keuntungan yang dibagikan perusahaan kepada pemegang saham dari tiap lembar sahamnya. Bagi investor, informasi laba per saham 
menggambarkan prospek laba di tahan perusahaan di masa depan. Perusahaan yang memiliki laba per saham yang tinggi maka nilai perusahaan tinggi.

Kegiatan perusahaan tidak terlepas dari hutang dan hutang yang dijadikan sebagai dana pada saat perusahaan memiliki defisit modal. Bagi investor, informasi hutang yang tinggi dapat menurunkan nilai perusahaan sehingga investor tidak tertarik dengan perusahaan yang memiliki hutang tinggi.

Pengembalian atas aset yang tinggi menunjukkan kinerja keuangan yang baik. Semakin tinggi pengembalian atas aset maka semakin efisien perputaran asetnya dan profit margin perusahaan juga senakin tinggi sehingga mengakibatkan peningkatkan nillai perusahaan.

Suku bunga menjadi salah satu ukuran keuntungan investasi yang diperoleh investor. Perbandingan terbalik terjadi pada suku bunga yang diikuti pergerakan saham dengan nilai perusahaan yang diukur dari harga sahamnya. Tingginya suku bunga BI memiliki dapat mengakibatkan turunnya nilai perusahaan.

Dari artikel pintersaham.id pada Februari 2019 menganalisis bahwa keseluruhan perusahaan whosale tercatat di Bursa Efek Indonesia menunjukkan perbandingan saham terlihat UNTR dominan memiliki keunggulan bersama dengan LTLS. Apabila dilihat dari profitabilitas UNTR menghasilkan angka rasio yang paling baik dibandingkan emiten lainnya. SPTO sendiri memiliki jumlah transaksi harian tergolong besar. Perusahaan memiliki debt to equity ratio rendah menunjukkan perusahaan makin baik. UNTR memiliki rasio DER paling rendah dibandingkan perusahaan lainnya. Pertumbuhan EPS paling tinggi dibandingkan dengan emiten lainnya adalah LTLS. Kemudian pendapatan dengan tingkat pertumbuhan tertinggi terdapat pada AKRA (https://pintarsaham.id/perbandingan-saham-sektor-perdagangan-besar-barangproduksi-di-bursa-efek-indonesia/).

Tabel 1. Laba bersih Setelah Pajak, Total Hutang, Total Aktiva, Suku Bunga dan Harga Saham Perusahaan Whosale yang Tercatat di BEI Periode 2014-2018

\begin{tabular}{|c|c|c|c|c|c|c|c|}
\hline No & $\begin{array}{c}\text { Kode } \\
\text { Emiten }\end{array}$ & Tahun & \begin{tabular}{c|} 
Laba Bersih \\
Setelah Pajak
\end{tabular} & Total Hutang & Total aktiva & $\begin{array}{c}\text { Suku } \\
\text { Bunga }\end{array}$ & Harga Saham \\
\hline \multirow[t]{5}{*}{1} & \multirow[t]{5}{*}{ AKRA } & 2014 & 790.563 .128 .000 & 8.824 .408 .103 .000 & 14.790 .103 .911 .000 & 7,75 & 4.120 \\
\hline & & 2015 & 1.058 .741 .020 .000 & 7.916 .954 .220 .000 & 15.203 .129 .563 .000 & 7,50 & 7.175 \\
\hline & & 2016 & 1.046 .852 .086 .000 & 7.756 .420 .389 .000 & 15.830 .740 .710 .000 & 4,75 & 6.000 \\
\hline & & 2017 & 1.001 .314 .446 .000 & 7.793 .559 .184 .000 & 16.823 .208 .531 .000 & 4,25 & 6.350 \\
\hline & & 2018 & 663.340 .794 .000 & 10.014 .019 .260 .000 & 19.940 .850 .599 .000 & 6 & 4.290 \\
\hline \multirow[t]{5}{*}{2} & \multirow[t]{5}{*}{ LTLS } & 2014 & 203.146 .000 .000 & 3.140 .124 .000 .000 & 4.674 .927 .000 .000 & 7,75 & 1.800 \\
\hline & & 2015 & 34.032 .000 .000 & 3.773 .710 .000 .000 & 5.393 .330 .000 .000 & 7,50 & 500 \\
\hline & & 2016 & 115.337 .000 .000 & 3.979 .344 .000 .000 & 5.658 .360 .000 .000 & 4,75 & 350 \\
\hline & & 2017 & 183.621 .000 .000 & 3.898 .250 .000 .000 & 5.769 .332 .000 .000 & 4,25 & 500 \\
\hline & & 2018 & 233.141 .000 .000 & 4.193 .399 .000 .000 & 6.318 .441 .000 .000 & 6 & 615 \\
\hline \multirow[t]{5}{*}{3} & \multirow[t]{5}{*}{ UNTR } & 2014 & 4.832 .049 .000 .000 & 21.777 .132 .000 .000 & 60.306 .777 .000 .000 & 7,75 & 17.350 \\
\hline & & 2015 & 2.792 .439 .000 .000 & 22.465 .074 .000 .000 & 61.715 .399 .000 .000 & 7,50 & 16.950 \\
\hline & & 2016 & 5.104 .477 .000 .000 & 21.369 .286 .000 .000 & 63.991.229.000.000 & 4,75 & 21.250 \\
\hline & & 2017 & 7.673 .322 .000 .000 & 34.724 .168 .000 .000 & 82.262 .093 .000 .000 & 4,25 & 35.400 \\
\hline & & 2018 & 11.498 .409 .000 .000 & 59.230 .338 .000 .000 & 116.281 .017 .000 .000 & 6 & 27.350 \\
\hline
\end{tabular}

\section{Sumber : www.dx.co.id}

Berdasarkan Tabel 1.1 di atas 3 perusahaan yang mewakili fenomena yang terjadi pada perusahaan wholesale yang sudah dikenal masyarakat menunjukkan bahwa PT. AKR Corporindo Tbk memiliki laba bersih setelah pajak di tahun 2017 sebesar Rp 1.001.314.446.000 mengalami penurunan dengan harga saham di tahun 2017 sebesar Rp 6.350 mengalami peningkatan. Tingkat suku bunga di tahun 2017 sebesar 4,25 mengalami penurunan dengan harga saham di tahun 2017 sebesar Rp 6.350 mengalami peningkatan. 
PT. Lautan Luas Tbk memiliki hutang di tahun 2018 sebesar Rp 4.193.399.000.000 mengalami peningkatan dengan harga saham di tahun 2016 sebesar Rp 615 mengalami penurunan. Tingkat suku bunga di tahun 2018 sebesar 6 mengalami peningkatan dengan harga saham di tahun 2018 sebesar Rp 615 mengalami peningkatan. Hal ini bertentang dengan teori Fahmi (2014), pada saat suku bunga mengalami kenaikan dan harga saham dipasar (market price) mengalami penurunan.

PT. United Tractors Tbk memiliki total aktiva di tahun 2018 sebesar Rp 116.281.017.000.000 mengalami peningkatan dengan harga saham di tahun 2018 sebesar Rp 27.350.

\section{LANDASAN TEORI}

\section{Nilai Perusahaan (Y)}

Menurut (Husnan \& Pudjiastuti, 2015), nilai perusahaan ialah harga yang dibayarkan pembeli atas saham perusahaan itu.

$P B V=$

$$
\frac{\text { Harga Saham }}{\text { Book Value }}
$$

Sumber : Wira (2015:99)

\section{Laba Per Saham $\left(X_{1}\right)$}

Menurut (Fahmi, 2014) earning per share ialah pemegang saham memperoleh laba atas tiap lembar saham yang dimilikinya. (Wira, 2015) EPS ialah rasio harga saham yang dipergunakan untuk menghitung PER.

Earning per share $=$

$$
\frac{\text { LabaSetelah Pajak }}{\text { JumlahLembar SahamBeredar }}
$$

Sumber : (Harmono, 2015)

\section{Rasio Hutang $\left(\mathbf{X}_{2}\right)$}

(Hery, 2016) rasio utang terhadap modal ialah ukuran berguna mengetahui besarnya utang terhadap modal perusahaan.

Debt To Equity Ratio =

$$
\frac{\text { Total Debt }}{\text { Total Equity }}
$$

Sumber : (Kasmir, 2016)

\section{Pengembalian Atas Aset $\left(\mathbf{X}_{3}\right)$}

(Khairunnisa, Taufik, \& Thamrin, 2019) Return On Asset (ROA) ialah ukuran yang menilai keuntungan yang diperoleh perusahaan dari aktiva yang dimilikinya. $\mathrm{ROA}=$

$$
\frac{\text { Earning After Tax }}{\text { Total assets }}
$$

Sumber : (Fahmi, 2014)

\section{Suku Bunga $\left(\mathrm{X}_{4}\right)$}

Menurut (Sudirman, 2013), suku bunga ialah perubahan tingkat suku bunga pada keadaan pasar uang dan akumulasi modal perekonomian.

\section{Pengaruh Laba Per Saham Terhadap Nilai Perusahaan}


Menurut (Walsh, 2012), meskipun jumlah absolut laba per saham tidak memberi tahu apa pun mengenai kinerjanya, EPS bertumbuh dari wakktu ke waktu. Sesungguhnya, direktur utama perusahaan yang menekankan hal itu sebagai target utama dalam laporan tahunan. Selain itu, pertumbuhan laba per saham sangat memengaruhi harga saham tersebut di bursa saham.

Dengan mengetahui EPS para investor bisa menilai potensi pendapatan per lembar saham dapat digunakan oleh pimpinan perusahaan untuk mengetahui perkembangan perusahaan, peningkatan laba secara total menunjukkan bahwa earning per share juga mengalami peningkatan, sehingga nilai saham mencerminkan naiknya nilai perusahaan (Innafisah, Afifuddin, \& Mawardi, 2019).

\section{Pengaruh Rasio Hutang Terhadap Nilai Perusahaan}

Menurut Fahmi (2014) penurunan nilai perusahaan diikuti naiknya hutang. (Noor, 2014) sebagian didanai dengan utang (equity + utang), maka rendahnya pajak penghasilan.

Semakin kecil utang dalam suatu perusahaan maka para investor akan senang dalam memberikan pendanaan karena laba perusahaan akan lebih banyak digunakan sebagai deviden dan hal itu akan meningkatkan nilai dari perusahaan tersebut (Sutama \& Lisa, 2018).

\section{Pengaruh Pengembalian Atas Aset Terhadap Nilai Perusahaan}

Menurut (Manurung, 2013) laba bersih naik mengakibatkan harga saham naik. Kenaikan laba bersih berkaitan dengan kenaikan pendapatan perusahaan.

Semakin besar ROA, berarti semakin efisien penggunaan aktiva perusahaan atau dengan kata lain dengan jumlah aktiva yang sama bisa dihasilkan laba yang lebih besar dan sebaliknya. Efisiensi perputaran asset dan atau semakin tinggi ROA yang diperoleh perusahaan, hal ini akan berdampak pada nilai perusahaan (Astarani \& Siregar, 2016).

\section{Pengaruh Suku Bunga Terhadap Nilai Perusahaan}

Menurut Fahmi (2014), penurunan harga saham diikuti dengan kenaikan suku bunga.

Suku bunga yang meningkat menyebabkan terjadinya peningkatan biaya modal perusahaan yang pada akhirnya akan mengurangi profitabilitas yang diperoleh perusahaan, karena adanya beban bunga yang meningkat yang harus dibayar perusahaan (Hendayana \& Riyanti, 2019).

\section{METODOLOGI PENELITIAN}

Metode penelitiannya asosiatif. Pendekatan yang dilakukan adalah dengan menggunakan pendekatan kuantitatif. Teknik pengumpulan adalah tinjauan pustaka dan dokumentasi. Peneliti memperoleh data penelitian dengan cara mem-broswing seluruh dokumen laporan keuangan perusahaan Whosale yang Tercatat di BEI Pada Periode 2014-2018.

Populasi penelitian ini adalah laporan keuangan perusahaan Whosale yang Tercatat di BEI Pada Periode 2014-2018 sebanyak 40. Sampel yang diambil sebanyak 17 perusahaan dengan menggunakan purposive sampling.

Sampel perusahaan sebanyak 17 perusahaan Whosale yang Tercatat di BEI Pada Periode 2014-2018 memiliki kriteria tertentu diuraikan pada tabel 2 sebagai berikut: 
Tabel 2. Sampel Penelitian

\begin{tabular}{|c|l|c|}
\hline No. & \multicolumn{1}{|c|}{ Kriteria } & Jumlah Sampel \\
\hline 1. & Perusahaan Whosale yang Tercatat di BEI Pada Periode 2014-2018 & 40 \\
\hline 2. & $\begin{array}{l}\text { Perusahaan Whosale menerbitkan laporan keuangan yang diaudit oleh } \\
\text { auditor independen secara lengkap Periode 2014-2018. }\end{array}$ & $(9)$ \\
\hline 3 & $\begin{array}{l}\text { Laporan keuangan Perusahaan Whosale mengalami kerugian Periode } \\
\text { Periode 2014-2018 }\end{array}$ & $(18)$ \\
\hline \multicolumn{2}{|c|}{ Jumlah Sampel Perusahaan } & 13 \\
\hline & Jumlah Sampel Penelitian (13 x 5) \\
\hline
\end{tabular}

Teknik analisis datanya kuantitatif dalam pengolahan data yang diteliti. Dengan melakukan asumsi klasik terdiri dari :

1. Uji Normalitas

Menurut (Ghozali, 2018) datanya normal atau tidak dilakukan pengujian ini. Biasanya diuji dengan histogram, normal p-plot dan One Sample Kolmogorov-Smirnov Test dengan kriteria :

a. Nilai signifikan atau 2-tailed $>0,05$ maka distribusi data normal.

b. Nilai signifikan atau 2-tailed $<0,05$ maka distribusi data tidak normal.

2. Uji Multikolineritas

Menurut (Ghozali, 2018) terdeteksi ada tidaknya multikolineritas dengan tolerance value dan variance inflation factor (VIF). Tolerance value dibawah 0,1 dan nilai VIF lebih besar dari pada 10 (VIF > 10) maka terjadi multikolinearitas. Sebaliknya jika tolerance value diatas 0,1 dan VIF lebih kecil daripada 10 (VIF < 10) maka tidak terjadi multikolinearitas.

3. Uji Autokorelasi

Menurut (Ghozali, 2018) Autokorelasi ini untuk menguji ada tidaknya variabel pengganggu dengan menggunakan uji Durbin-Watson (DW) test.

4. Uji Heterokedastisitas

Menurut (Ghozali, 2018) heteroskedastisitas ini pengujian untuk membandingkan pengamatan yang satu ke pengamatan lain.

Selain asumsi klasik pengujian tetapi dilakukan pengujian hipotesis. Pengujian hipotesis penelitian menggunakan analisis regresi linear berganda disebabkan variabel penelitian ini lebih dari satu variabel independen dengan persamaan sebagai berikut :

$$
\mathrm{Y}=\mathrm{a}+\mathrm{b}_{1} \mathrm{X}_{1}+\mathrm{b}_{2} \mathrm{X}_{2}+\mathrm{b}_{3} \mathrm{X}_{3}+\mathrm{b}_{4} \mathrm{X}_{4}+\mathrm{e}
$$

\section{Keterangan :}

Y : Nilai Perusahaan

a : konstanta

$\mathrm{X}_{1} \quad$ : Laba per Saham

$\mathrm{X}_{2} \quad$ : Rasio Hutang

$\mathrm{X}_{3} \quad$ : Pengembalian atas aset

$\mathrm{X}_{4} \quad$ : Suku bunga

$\mathrm{b}_{1,2,3,4}$ : besaran koefisien regresi dari masing-masing variable

e : error

\section{Pengujian Hipotesis}

Koefisien Determinasi $\left(\mathbf{R}^{2}\right)$ 
Melihat seberapa besar kemampuan independen mempengaruhi dependen dengan ketentuan :

1. $\mathrm{R}=1 \quad$ : Bersifat sempurna

2. R mendekati 1 : Sangat erat dan searah

3. R mendekati -1 : Sangat erat dan tidak searah

4. R mendekati 0 : Sangat lemah

5. $\mathrm{R}=0 \quad$ : Tidak ada hubungan sama sekali

Nilai koefisien determinasi yang baik diantara 0 samapai 1.

\section{Uji F-Statistik}

Keseluruhan bebas variabelnya bersama mempengaruhi terikat variabel dengan ketentuan Fhitung $>$ Ftabel.

\section{Uji Koefisien Parameter Individual (Uji Statistik t)}

Secara individual variabel bebasnya mempengaruhi variabel terikatnya dengan ketentuan thitung $>$ ttabel.

\section{HASIL PENELITIAN}

Terpenuhinya sampel 13 perusahaan Whosale yang Tercatat di BEI dengan 5 tahun diamati jumlahnya 65. Deskripsinya diuji yaitu :

Tabel 3. Deskriptif Statistik

\section{Descriptive Statistics}

\begin{tabular}{lr|r|r|r|r} 
& N & \multicolumn{1}{c|}{ Minimum } & Maximum & \multicolumn{1}{c}{ Mean } & \multicolumn{1}{c}{ Std. Deviation } \\
\hline EPS & 65 & 2.84 & 3082.57 & 251.8455 & 493.71240 \\
\hline DER & 65 & .04 & 4.14 & 1.3092 & 1.05744 \\
\hline ROA & 65 & .00 & .11 & .0546 & .02862 \\
\hline BIRate & 65 & 4.25 & 7.75 & 6.0500 & 1.41986 \\
\hline PBV & 65 & .32 & 7.35 & 1.5771 & 1.27451 \\
\hline Valid N (listwise) & 65 & & & & \\
\hline
\end{tabular}

Sumber: diolah data

Penjabaran deskriptif statistik :

1. Sampelnya 65 untuk laba per saham, nilai terendah 2,84 , max $3.082,57$, mean 251,8455 dan std deviasi 493,71240.

2. Sampelnya 65 untuk rasio hutang, nilai terendah 0,04 , max 4,14, mean 1,3092 dan std deviasi 1,05744 .

3. Sampelnya 65 untuk pengembalian atas aset, nilai terendah 0,00 , max 0,11 , mean 0,0546 dan std deviasi 0,02862 .

4. Sampelnya 65 untuk suku bunga, nilai terendah 4,25, max 7,75, mean 6,0500 dan std deviasi 1,41986.

5. Sampelnya 65 untuk nilai perusahaan, nilai terendah 0,32 , max 7,35, mean 1,5771 dan std deviasi 1,27451.

\section{Asumsi Klasik}

\section{Normalitas}

Normalitas ada dua : grafik dan statistik. Grafik normalitas terlihat normal berbentuk parabola terbalik. Histogram ini disajikan: 


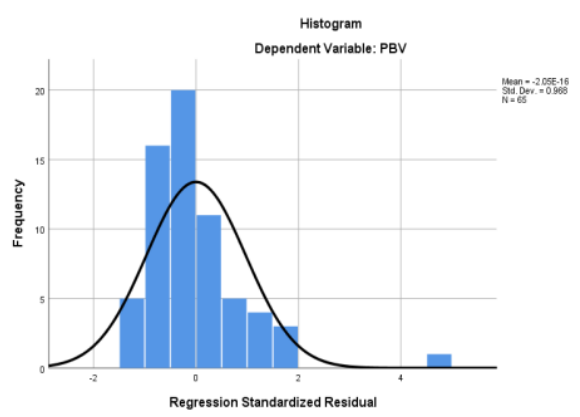

\section{Gambar 4.1 Histogram Sebelum Transformasi}

Grafik histogram miring kekanan maupun kiri, tidak membentuk parabola terbalik jadi data tidak normal. Data dinormalkan dengan tranformasi ln untuk tiap variabelnya dengan grafik :

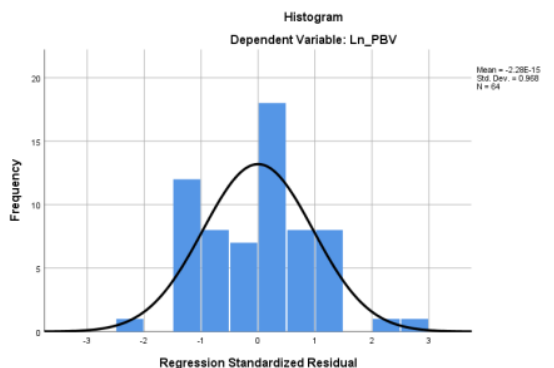

\section{Gambar 4.2 Histogram Sesudah Transformasi}

Grafik histogram memperlihatkan tiak miring kekanan maupun kiri, membentuk sebuah parabola terbalik jadi data normal.

Grafik normal p-p-plot dapat diperlihatkan berikut :

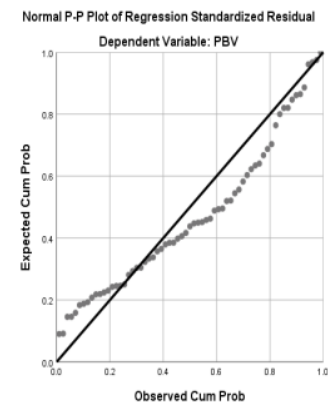

Gambar 4.3. Normal p-p-Plot Sebelum Transformasi

Grafik normal p-p-plot terlihat titik menjauhi garis diagonalnya jadi data tidak normal. Data dinormalkan dengan tranformasi ln untuk tiap variabelnya dengan grafik :

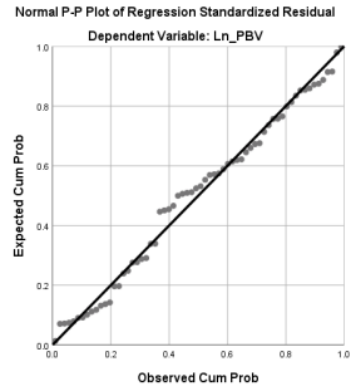

Gambar 4.4 Normal Probability Plot Sesudah Transformasi 

normal.

Grafik normal p-p-plot memperlihatkan titik mendekati garis diagonalnya jadi data

Penyajian one-sample kolmogorov smirnov berikut :

Tabel 4. One-Sample Kolmogorov-Smirnov Test Sebelum Transformasi

\section{One-Sample Kolmogorov-Smirnov Test}

\begin{tabular}{llr} 
& & $\begin{array}{r}\text { Unstandardized } \\
\text { Residual }\end{array}$ \\
\hline $\mathrm{N}$ & Mean & 65 \\
\cline { 2 - 3 } Normal Parameters & Std. Deviation & .0000000 \\
\hline Most Extreme Differences & Absolute & 1.17249649 \\
\cline { 2 - 3 } & Positive & .140 \\
\cline { 2 - 3 } & Negative & .140 \\
\hline Test Statistic & & .107 \\
\hline Asymp. Sig. (2-tailed) & $.003^{c}$ \\
\hline a. Test distribution is Normal. & \\
b. Calculated from data. & \\
c. Lilliefors Significance Correction. & \\
\end{tabular}

Sig 0,003 yang tertera pada one-sample kolmogorov smirnov terlihat data tidak normal. Data dinormalkan dengan tranformasi ln tiap variabelnya :

Tabel 5. One-Sample Kolmogorov-Smirnov Test Sesudah Transformasi

One-Sample Kolmogorov-Smirnov Test

\begin{tabular}{llr} 
& & $\begin{array}{c}\text { Unstandardized } \\
\text { Residual }\end{array}$ \\
\hline N & Mean & 64 \\
\cline { 2 - 3 } & Std. Deviation & .0000000 \\
\hline Most Extreme Differences & Absolute & .68714737 \\
\cline { 2 - 3 } & Positive & .085 \\
\cline { 2 - 3 } & Negative & .069 \\
\hline Test Statistic & & .085 \\
\hline Asymp. Sig. (2-tailed) & & .085 \\
\hline
\end{tabular}

a. Test distribution is Normal.

b. Calculated from data.

c. Lilliefors Significance Correction.

d. This is a lower bound of the true significance. normal.

Sig 0,200 yang tertera pada one-sample kolmogorov smirnov memperlihatkan data

\section{Uji Multikolinearitas}

Multikolinearitas ketentuan VIF $<10$ dan tolerance $>0,1$ disajikan :

Tabel 6. Hasil Uji Multikolinieritas Sebelum Transformasi

\begin{tabular}{|c|c|c|c|}
\hline & & Collinearity & istics \\
\hline & Model & Tolerance & VIF \\
\hline 1 & (Constant) & & \\
\hline & EPS & .833 & 1.201 \\
\hline & DER & .828 & 1.207 \\
\hline & ROA & .708 & 1.411 \\
\hline & BIRate & .990 & 1.011 \\
\hline
\end{tabular}

Laba per saham, rasio hutang, pengembalian atas aset dan suku bunga memiliki tolerance $>0,1$ dan VIF $<10$ memperlihatkan tidak multikolinieritas. 
Tabel 7. Hasil Uji Multikolinieritas Sesudah Transformasi

\begin{tabular}{|c|c|c|c|}
\hline \multirow{2}{*}{\multicolumn{2}{|c|}{ Model }} & \multicolumn{2}{|c|}{ Collinearity Statistics } \\
\hline & & Tolerance & VIF \\
\hline \multirow[t]{5}{*}{1} & (Constant) & & \\
\hline & Ln_EPS & .578 & 1.731 \\
\hline & Ln_DER & .746 & 1.341 \\
\hline & Ln_ROA & .498 & 2.007 \\
\hline & Ln_BIRate & .984 & 1.016 \\
\hline
\end{tabular}

Laba per saham, rasio hutang, pengembalian atas aset dan suku bunga memiliki tolerance $>0,1$ dan VIF $<10$ memperlihatkan tidak multikolinieritas.

\section{Uji Autokorelasi}

Autokorelasi sifatnya blue dengan ketentuan $\mathrm{du}<\mathrm{dw}<4-\mathrm{du}$.

Tabel 8. Hasil Uji Autokorelasi Sebelum Transformasi

\begin{tabular}{|c|c|c|c|c|c|}
\hline \multirow[b]{2}{*}{ Model } & \multicolumn{5}{|c|}{ Model Summary } \\
\hline & $\mathrm{R}$ & $\mathrm{R}$ Square & Adjusted R Square & $\begin{array}{l}\text { Std. Error of the } \\
\text { Estimate }\end{array}$ & Durbin-Watson \\
\hline
\end{tabular}

a. Predictors: (Constant), BIRate, ROA, EPS, DER

b. Dependent Variable: PBV

$\mathrm{Dw}=2,040, \mathrm{~N}=65, \mathrm{du}=1,7311, \mathrm{du}<\mathrm{dw}<4-\mathrm{du}, \quad 1,7311<2,040<4-1,7311$ hingga $, 7311<2,040<2,2689$ data tidak ada autokorelassi.

Tabel 9. Hasil Uji Autokorelasi Sesudah Transformasi

\begin{tabular}{|c|c|c|c|c|c|}
\hline \multirow[b]{2}{*}{ Model } & \multicolumn{5}{|c|}{ Model Summary } \\
\hline & $\mathrm{R}$ & R Square & Adjusted R Square & $\begin{array}{l}\text { Std. Error of the } \\
\text { Estimate }\end{array}$ & Durbin-Watson \\
\hline 1 & $.502^{\mathrm{a}}$ & .252 & .201 & .71006 & 2.132 \\
\hline
\end{tabular}

a. Predictors: (Constant), Ln_BIRate, Ln_EPS, Ln_DER, Ln_ROA

b. Dependent Variable: Ln_PBV

$\mathrm{Dw}=2,132, \mathrm{~N}=64, \mathrm{du}=1,7303, \mathrm{du}<\mathrm{dw}<4-\mathrm{du}, 1,7303<2,132<4-1,7303$ hingga $1,7303<2,132<2,2697$ data tidak ada autokorelasi.

\section{Uji Heteroskedastisitas}

Uji heteroskedastisitas menggunakan metode grafik dan statistik. GrafikScatterplot yang memenuhi ketentuan titik tersebar secara acak dan tidak berpola menunjukkan tidak ada heterokedatisitas.

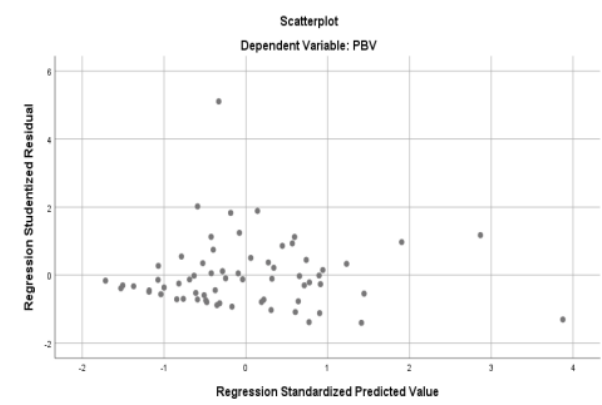

\section{Gambar 4.5 Scatterplot Sebelum Transformasi}

GrafikScatterplot yang memenuhi ketentuan titik tersebar secara acak dan berpola menunjukkan ada heterokedatisitas. 


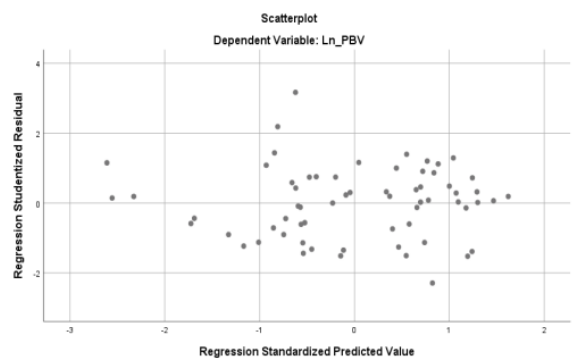

Gambar 4.6 Scatterplot Sesudah Transformasi

GrafikScatterplot yang memenuhi ketentuan titik tersebar secara acak dan tidak berpola menunjukkan tidak ada heterokedatisitas.

Pengujian Glejser pada Tabel 3.8 berikut ini

Tabel 10. Hasil Uji Glejser Sebelum Transformasi

Coefficients $^{\mathrm{a}}$

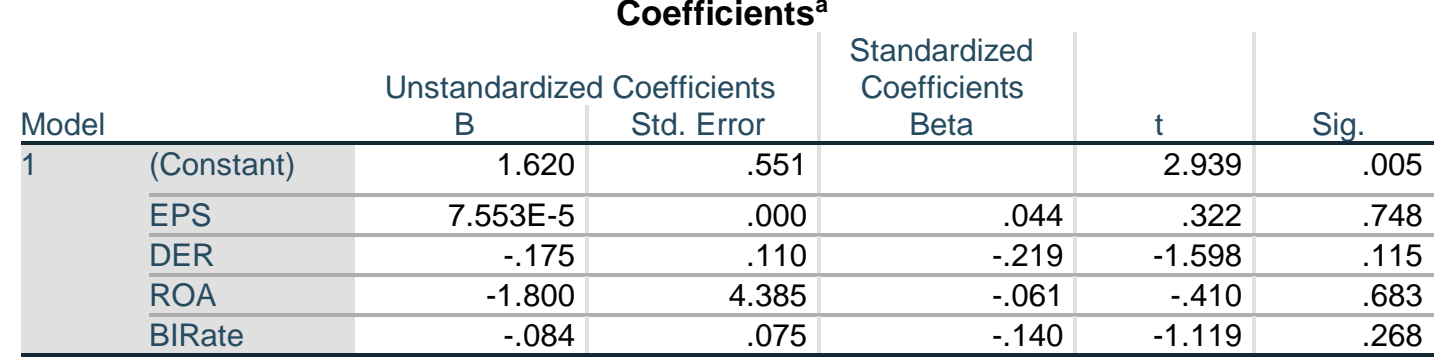

a. Dependent Variable: Abs_ut

Sig laba per saham, rasio hutang, pengembalian atas aset dan suku bunga $>0,05$ tidak heteroskedastisitas.

Tabel 11. Hasil Uji Glejser Sesudah Transformasi Coefficients $^{\mathbf{a}}$

\begin{tabular}{|c|c|c|c|c|c|c|}
\hline \multicolumn{7}{|c|}{ Coefficients $^{a}$} \\
\hline & & \multicolumn{2}{|c|}{ Unstandardized Coefficients } & \multirow{2}{*}{$\begin{array}{c}\text { Standardized } \\
\text { Coefficients } \\
\text { Beta }\end{array}$} & \multirow[b]{2}{*}{$\mathrm{t}$} & \multirow[b]{2}{*}{ Sig. } \\
\hline \multicolumn{2}{|c|}{ Model } & B & Std. Error & & & \\
\hline \multirow[t]{5}{*}{1} & (Constant) & .839 & .658 & & 1.274 & .208 \\
\hline & Ln_EPS & -.013 & .046 & -.046 & -.283 & .778 \\
\hline & Ln_DER & -.138 & .070 & -.281 & -1.978 & .053 \\
\hline & Ln_ROA & -.081 & .117 & -.120 & -.688 & .494 \\
\hline & Ln_BIRate & -.277 & .213 & -.161 & -1.300 & .199 \\
\hline
\end{tabular}

a. Dependent Variable: Abs_ut1

Sig laba per saham, rasio hutang, pengembalian atas aset dan suku bunga $>0,05$ tidak heteroskedastisitas.

\section{Hasil Analisis Data}

\section{Analisis Regresi Linier Berganda}

Analisis regresi linear berganda menguji adanya kenaikan atau penurunan variabel independen terhadap variabel dependen. Hasil pengujiannya : 
Tabel 12. Hasil Analisis Regresi Linier Berganda Coefficients $^{\mathrm{a}}$

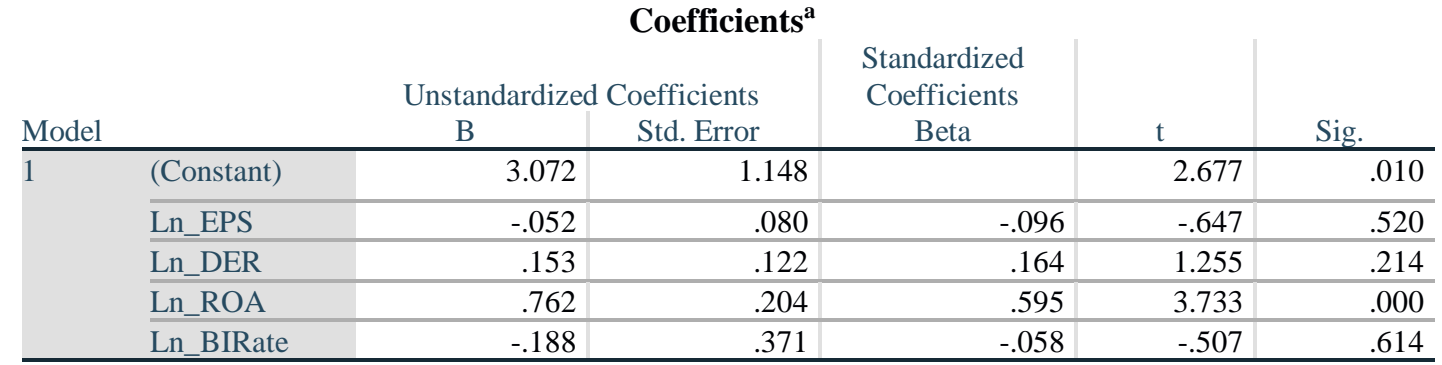

a. Dependent Variable: Ln_PBV

Ln_PBV $=3,072$ - 0,052 Ln_EPS + 0,153 Ln_DER + 0,762 Ln_ROA - 0,188 Ln_BI Rate

1. Konstanta 3,072 berarti laba per saham, rasio hutang, pengembalian atas aset dan suku bunga dianggap nol dengan nilai perusahaan 3,072.

2. Laba per saham $-0,052$ berarti meningkatnya laba per saham satu kali maka nilai perusahaan menurun 0,052 .

3. Rasio hutang 0,153 berarti meningkatnya rasio hutang satu kali maka nilai perusahaan meningkat 0,153 .

4. Pengembalian atas aset 0,762 berarti meningkatnya pengembalian atas aset satu kali maka nilai perusahaan meningkat 0,762 .

5. Suku bunga $-0,188$ berarti meningkatnya suku bunga satu kali maka nilai perusahaan menurun 0,188 .

\section{Koefisien Determinasi $\left(\mathbf{R}^{2}\right)$}

Koefisien determinasi mengukur seberapa kemampuan variabel bebas dapat menjelaskan variabel terikat.

Tabel 13. Koefisien Determinasi Model Summary ${ }^{b}$

\begin{tabular}{|c|c|c|c|c|}
\hline \multicolumn{5}{|c|}{ Mroder summary } \\
\hline Model & $\mathrm{R}$ & R Square & Adjusted R Square & $\begin{array}{l}\text { Std. Error of the } \\
\text { Estimate }\end{array}$ \\
\hline 1 & $.502^{\mathrm{a}}$ & .252 & .201 & .71006 \\
\hline
\end{tabular}

Adjusted R Squarenya 0,201 dengan pengaruh 20,1\%\% terhadap nilai perusahaan dan sisanya 79,9\% dipengaruhi variabel lainnya.

\section{Pengujian Hipotesis Secara Simultan (Uji Statistik F)}

Uji $\mathrm{F}$ digunakan untuk menguji apakah variabel independen secara bersama-sama mempengaruhi variabel dependen.

\begin{tabular}{|c|c|c|c|c|c|c|}
\hline \multirow[b]{2}{*}{ Model } & \multicolumn{6}{|c|}{$\begin{array}{l}\text { 4. Hasil Uji } \\
\text { ANOVA }^{\mathbf{a}}\end{array}$} \\
\hline & & Sum of Squares & df & Mean Square & $\mathrm{F}$ & Sig. \\
\hline 1 & Regression & 10.020 & 4 & 2.505 & 4.968 & $.002^{\mathrm{b}}$ \\
\hline & Residual & 29.747 & 59 & .504 & & \\
\hline & Total & 39.767 & 63 & & & \\
\hline
\end{tabular}

a. Dependent Variable: Ln_PBV

b. Predictors: (Constant), Ln_BIRate, Ln_EPS, Ln_DER, Ln_ROA

$F_{\text {hitung }}=4,968$, sig $=0,002$ dan $F_{\text {tabel }}(64-5=59)=2,53 . \quad F_{\text {hitung }}>F_{\text {tabel }}$ yaitu 4,968>2,53 terlihat $\mathrm{H}_{0}$ ditolak, $\mathrm{H}_{\mathrm{a}}$ diterima ditunjukkan laba per saham, rasio hutang, 
pengembalian atas aset dan suku bunga berpengaruh terhadap nilai perusahaan pada perusahaan Whosale yang Tercatat di BEI.

\section{Pengujian Hipotesis Secara Parsial (Uji Statistik t)}

Uji t menguji apakah variabel independen secara individual mempengaruhi variabel dependen.

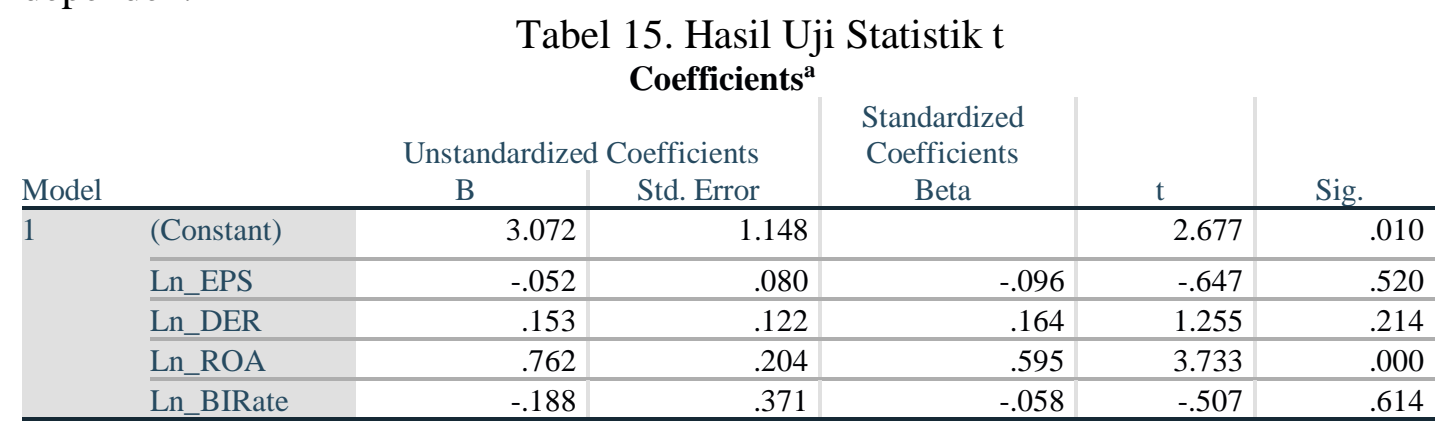

a. Dependent Variable: Ln_PBV

1. Laba per saham $t_{\text {hitung }}=-0,647$, sig $=0,520$, $t_{\text {tabel }}(64-4=60)=2,000$, $-t_{\text {hitung }}>-t_{\text {tabel, }}$ $0,647>-2,000 \mathrm{H}_{0}$ diterima, $\mathrm{H}_{\mathrm{a}}$ ditolak ditunjukkan laba per saham tidak berpengaruh terhadap nilai perusahaan pada perusahaan Whosale yang Tercatat di BEI.

2. Rasio hutang $t_{\text {hitung }}=1,255$, sig $=0,214$, $t_{\text {tabel }}(64-4=60)=2,000 t_{\text {hitung }}>t_{\text {tabel, }}, 1255<$ 2,000 $\mathrm{H}_{0}$ diterima, $\mathrm{H}_{\mathrm{a}}$ ditolak ditunjukkan rasio hutang tidak berpengaruh terhadap nilai perusahaan pada perusahaan Whosale yang Tercatat di BEI.

3. Pengembalian atas aset $t_{\text {hitung }}=3,733$, sig $=0,000$, $t_{\text {tabel }}(64-4=60)=2,000$, $\mathrm{t}_{\text {hitung }}>$ $\mathrm{t}_{\text {tabel, }}, 3,733>2,000 \mathrm{H}_{0}$ ditolak, $\mathrm{H}_{\mathrm{a}}$ diterima ditunjukkan pengembalian atas aset berpengaruh terhadap nilai perusahaan pada perusahaan Whosale yang Tercatat di BEI.

4. Suku bunga $\mathrm{t}_{\text {hitung }}=-0,507$, sig $=0,614$, $\mathrm{t}_{\text {tabel }}(64-4=60)=2,000$, $-\mathrm{t}_{\text {hitung }}>-\mathrm{t}_{\text {tabel, }}$ $0,507>-2,000 \mathrm{H}_{0}$ diterima, $\mathrm{H}_{\mathrm{a}}$ ditolak ditunjukkan suku bunga tidak berpengaruh terhadap nilai perusahaan pada perusahaan Whosale yang Tercatat di BEI.

\section{Pembahasan}

\section{Pengaruh Laba Per Saham Terhadap Nilai Perusahaan}

Hasil penelitian ini adalah laba per saham tidak berpengaruh terhadap nilai perusahaan pada perusahaan Whosale yang Tercatat di BEI.

Hasil ini juga didukung oleh penelitian (Indriawati, 2018) yang juga membuktikan Earning Per Share tidak berpengaruh terhadap nilai perusahaan.

Hasil penelitian tidak konsisten dengan (Walsh, 2012), meskipun jumlah absolut laba per saham tidak memberi tahu apa pun mengenai kinerja perusahaan, pertumbuhan EPS dari waktu ke waktu merupakan statistik yang sangat penting. Sesungguhnya, direktur utama perusahaan yang menekankan hal itu sebagai target utama dalam laporan tahunan. Pertumbuhan laba per saham sangat memengaruhi harga saham tersebut di bursa saham.

\section{Pengaruh Rasio Hutang Terhadap Nilai Perusahaan}

Hasil penelitian ini adalah rasio hutang tidak berpengaruh terhadap nilai perusahaan pada perusahaan Whosale yang Tercatat di BEI.

Hasil ini juga didukung oleh penelitian (Indriawati, 2018) yang juga membuktikan Debt to Equity Ratio tidak berpengaruh terhadap nilai perusahaan.

Hasil penelitian ini tidak konsisten dengan Fahmi (2014) hutang yang tinggi menurunkan nilai perusahaan. 


\section{Pengaruh Pengembalian Atas Aset Terhadap Nilai Perusahaan}

Hasil penelitian ini adalah pengembalian atas aset berpengaruh terhadap nilai perusahaan pada perusahaan Whosale yang Tercatat di BEI. Hasil penelitian ini didukung oleh hasil penelitian (Irnawati, 2019) yang membuktikan ROA berpengaruh positif signifikan terhadap nilai perusahaan. Begitu juga pada penelitian (Husna \& Satria, 2019) yang menunjukkan bahwa ROA berpengaruh positif dan signifikan terhadap nilai perusahaan.

Hasil penelitian ini konsisten Manurung (2013) laba bersih naik mengakibatkan harga saham naik. Kenaikan laba bersih berkaitan dengan kenaikan pendapatan perusahaan.

\section{Pengaruh Suku Bunga Terhadap Nilai Perusahaan}

Hasil penelitian ini adalah suku bunga tidak berpengaruh terhadap nilai perusahaan pada perusahaan Whosale yang Tercatat di BEI.

Hasil ini didukung oleh hasil penelitian (Pangestuti \& Louisa, 2020) yang juga membuktikan jika suku bunga tidak berpengaruh terhadap nilai perusahaan.

Hasil penelitian ini tidak konsisten Fahmi (2014), pada saat suku bunga mengalami kenaikan dan harga saham dipasar (market price) mengalami penurunan.

\section{KESIMPULAN}

Berdasarkan pada hasil penelitian, maka dapat ditarik beberapa kesimpulan sebagaiberikut:

1. Laba persaham tidak berpengaruh terhadap nilai perusahaan pada perusahaan Whosale yang Tercatat di BEI.

2. Rasio hutang tidak berpengaruh terhadap nilai perusahaan pada perusahaan Whosale yang Tercatat di BEI.

3. Pengembalian atas aset berpengaruh terhadap nilai perusahaan pada perusahaan Whosale yang Tercatatdi BEI.

4. Suku bunga tidak berpengaruh terhadap nilai perusahaan pada perusahaan Whosale yangTercatat di BEI.

5. Laba per saham, rasio hutang, pengembalian atas aset dan suku bunga berpengaruh terhadap nilai perusahaan pada perusahaan Whosale yang Tercatat diBEI.

\section{DAFTAR PUSTAKA}

Astarani, J., \& Siregar, J. S. (2016). Pengaruh Return on Asset (ROA) Terhadap Nilai Perusahaan dengan Pengungkapan Corporate Social Responsibility (CSR) sebagai

Variabel Pemoderasi pada Perusahaan Manufaktur yang terdaftar di Bursa Efek Indonesia (BEI). Jurnal Audit dan Akuntansi Fakultas Ekonomi dan Bisnis Universitas Tarumanegara, 49-76.

Fahmi, I. (2014). Pengantar Manajemen Keuangan. Bandung: Alfabeta.

Fahmi, I. (2014). Pengantar Perbankan Teori dan Aplikasi. Bandung: Alfabeta.

Ghozali, I. (2018). Aplikasi Analysis Multivariate dengan Program SPSS. Semarang: BPUniversitas Dipenogoro.

Harmono. (2015). Manajemen Keuangan Berbasis Balance Scorecard. Jakarta: Bumi Aksara. 
Hendayana, Y., \& Riyanti, N. (2019). Pengaruh Inflasi, Suku Bunga, Likuiditas dan Leverage terhadap Nilai Perusahaan (Studi Empiris : Perusahaan Perkebunan yang Terdaftar di BEI Periode 2012-2017). Jurnal Ekonomi dan Bisnis , 36-48.

Hery. (2016). Financial Ratio for Business. Jakarta: PT. Grasindo.

Husna, A., \& Satria, I. (2019). Effects of Return on Asset, Debt to Asset Ratio, Current Ratio, Firm Size, and Dividend Payout Ratio on Firm Value . International Journal of Economics and Financial Issues , 50-54.

Husnan, S., \& Pudjiastuti, E. (2015). Dasar-Dasar Manajemen Keuangan. Yogyakarta: UPP STIM YKPN.

Indriawati, F. (2018). The Impact of Profitability, Debt Policy, Earning Per Share, and Dividend Policy on The Firm Value (Empirical Study of Companies Listed in Jakarta Islamic Index 2013-2015. Information and Knowledge Management , 2334.

Innafisah, L., Afifuddin, \& Mawardi, M. C. (2019). Pengaruh Earning Per Share (EPS), Price Earning Ratio (PER) dan Dividend Payout Ratio (DPR) terhadap Nilai Perusahaan Property dan Real Estate yang Terdaftar di Bursa Efek Indonesia (BEI) Periode 2014-2017. Jurnal Fakultas Ekonomi dan Bisnis Universitas Islam Malang , 37-52.

Irnawati, J. (2019). Pengaruh Return on Assets (ROA), Return on Equity (ROE) dan Current Ratio (CR) terhadap Nilai Perusahaan dan Dampaknya terhadap Kebijakan Dividen (Studi Kasus pada Perusahaan Construction and Engineering yang terdaftar di Bursa Efek Singapura). Jurnal Sekuritas , 1-13.

Kasmir. (2016). Analisis Laporan Keuangan. Jakarta: Raja Grafindo Persada.

Khairunnisa, T., Taufik, \& Thamrin, K. M. (2019). Pengaruh Debt to Equity Ratio, Return on Assets, Assets Growth, Current Ratio dan Total Assets Turnover terhadap Nilai Perusahaan pada Perusahaan Sektor Makanan dan Minuman yang terdaftar di Bursa Efek Indonesia. Jurnal Ilmiah Manajemen Bisnis dan Terapan , 31-44.

Manurung, A. H. (2013). Pengelolaan Portofolio Obligasi. Jakarta: Gramedia.

Noor, H. F. (2014). Investasi, Pengelolaan Keuangan, dan Pengembangan Ekonomi Masyarakat. Jakarta: Mitra Wacana Media.

Pangestuti, D. C., \& Louisa, A. M. (2020). The Influence of Internal and External Factors on Firm Value. European Journal of Business and Management Research , 1-6.

Sudirman, I. W. (2013). Manajemen Perbankan Menuju Bankir Konvensional yang Profesional. Jakarta: Kencana.

Sutama, D. R., \& Lisa, E. (2018). Pengaruh Leverage dan Profitabilitas terhadap Nilai Perusahaan (Studi pada Perusahaan Sektor Manufaktur Food and Beverage yang Terdaftar di Bursa Efek Indonesia. Jurnal Sains Manajemen \& AKuntansi , 21-39.

Walsh, C. (2012). Key Management Ratio. Jakarta: Erlangga.

Wira, D. (2015). Analisis Fundamental Saham. Jakarta: Exceed. 